\title{
A RARE FORM OF REFLEX EPILEPSY: HOT WATER EPILEPSY
}

\author{
Nadir Bir Refleks Epilepsi Türü: Sıcak Su Epilepsisi
}

\section{Özgür TATLI ${ }^{1}$, Selim YURTSEVER ${ }^{1}$, Mücahit GÜNAYDIN ${ }^{1}$, Faruk ÖZŞAHİN ${ }^{1}$, Gürkan ALTUNTAŞ ${ }^{1}$, Nurhak AKSÜT ${ }^{1}$}

${ }^{1}$ Karadeniz Technical University School of Medicine, Farabi Hospital Emergency Department, Trabzon, TURKEY

\section{ABSTRACT}

Hot water epilepsy is a rare form of reflex epilepsy. It is generally precipitated by hot water being poured on the head while bathing. It is generally seen in healthy children and is more common in males. Our case was a 12-year-old girl. She underwent consecutive episodes during intervention at the emergency department after washing with hot water. She was intubated when her oxygen saturations fell. Her head region had not come into contact with hot water. Hot water epilepsy generally follows a benign course and is a self-limiting form of reflex epilepsy. It does not usually require treatment for subsequent periods. The patient should be advised to avoid hot water and long baths.

Keywords: Emergency department, hot water epilepsy, reflex epilepsy
Sıcak su epilepsisi refleks epilepsilerin nadir bir türüdür. Genelde banyo esnasında sıcak suyun kafaya aniden dökülmesi ile tetiklenir. Genelde sağlıklı çocuklarda ve erkek cinsiyette görülür. Bizim vakamız 12 yaşında bir kız çocuğu idi. Sıcak suyla yıkandıktan sonra acil servise getirilen hastada tekrarlayıcı nöbet epizotları meydana geldi. Oksijen saturasyonlarının düşmesi üzerine entübe edildi. Hastanın kafa bölgesine herhangi bir sıcak su teması olmamış. Sicak su epilepsileri genelde iyi seyirli olup sonraki dönemler için tedavi başlanmaz. Hastalara sonraki dönemler için sıcak sudan ve uzun banyolardan kaçınılması önerilir.

Anahtar Kelimeler: Acil servis, refleks epilepsi, sicak su epilepsisi 


\section{INTRODUCTION}

Reflex epilepsies represent approximately 6\% of all epilepsies. Hot water epilepsy is a rare form of reflex epilepsy. It generally occurs after the head region comes into contact with hot water (2). Most cases have been reported from southern India $(3,4)$. This strengthens the idea that hot water epilepsy exhibits genetic and regional characteristics. Cases of hot water epilepsy have been reported in Turkey and other countries, albeit rarely (5). As in our case, episodes begin in early childhood and adolescence (6).

\section{CASE REPORT}

A 12-year-old girl injured as a result of washing with hot water was brought to the emergency department. When she arrived, she had first-second degree burns on $40 \%-45 \%$ of the surface of her back and the back of the legs. Her face, neck and genital area were unaffected. Vital findings were as follows: arterial blood pressure was $60 / 40 \mathrm{~mm} / \mathrm{Hg}$, pulse was 100 beats/min and oxygen saturation was $\left(\mathrm{O}_{2} \mathrm{~S}\right) 98 \%$. She was lucid, oriented and co-operative, with a Glasgow Coma Scale score of 15 . The patient was started on intravenos (IV) fluid resuscitation. The administration of $4800 \mathrm{cc}$ lactated Ringer's solution in 24 hour (h) was scheduled; $300 \mathrm{cc} / \mathrm{h}$ IV fluid resuscitation was started for the first $8 \mathrm{~h}$. A urinary catheter was installed and $0.5 \mathrm{cc}$ tetanus toxoid was administered as prophylaxis. Forty micrograms of fentanyl were administered IV for analgesia. The burn area was cooled with saline solution and cleaned with diluted antiseptic solutions. One percent silver sulfadiazine, a topical antimicrobial, was applied to the entire wound surface and the affected areas were covered with burn dressings. While fluid resuscitation was continuing, the patient underwent a tonic clonic seizure lasting $1 \mathrm{~min}$. The episode was halted with the administration of $5 \mathrm{mg}$ diazepam IV. At this time the patient's arterial blood pressure was $40 / 20 \mathrm{~mm} / \mathrm{Hg}$, pulse 140 beats/min and $\left(\right.$ sat $\mathrm{O}_{2}$ ) was $96 \%$. A second tonic clonic episode occurred 5 minute after the first and that these were the first she had experienced. The diazepam. Laboratory results were as follows: glucose was $227 \mathrm{mg} / \mathrm{dl}$, BUN/creatinine was 10/0.6 $\mathrm{mg} / \mathrm{dl}$, alanine transaminase was $39 \mathrm{U} / \mathrm{L} \quad(0-65 \mathrm{U} / \mathrm{L})$, aspartate transaminase was $69 \mathrm{U} / \mathrm{L}(0-35 \mathrm{U} / \mathrm{L}), \mathrm{Na}$ was 140 $\mathrm{meq} / \mathrm{L}$ and $\mathrm{K}$ was $4.4 \mathrm{meq} / \mathrm{L}$. The patient was transferred to the university hospital, the regional reference hospital. Episodes continued there. She was intubated when her oxygen saturation fell. The patient was started on $2 \mathrm{mg} / \mathrm{h}$ midazolam infusion, and 20 $\mathrm{mg} / \mathrm{kg}$ phenytoin was given for antiepileptic purposes. Head Computed Tomography (CT) was normal. No pathology was observed at magnetic resonance 1maging (MRG) or electroencephalography (EEG). After being respirated with a mechanical ventilator for $24 \mathrm{~h}$, the patient was extubated. No further problem was experienced at follow-ups and the patient was discharged on the fifth day of hospitalization.

\section{DISCUSSION}

Hot water epilepsy is a rare form of reflex epilepsy that develops after contact with hot water. The first case report of hot water epilepsy was by Allen et al. in 1945 (7). Febrile convulsion and head trauma may be seen in the histories of patients developing hot water epilepsy (8). A family history of epilepsy of $18-22 \%$ has been reported $(8,9)$. The mechanism involved in this form of epilepsy is unclear, although it is thought to result from a sudden thermal skin stimulus stimulating the thermoregulatory center (10). Contact with water at 45 ${ }^{\circ} \mathrm{C}$ and above increases the probability of this mechanism being activated. Males represent $70 \%$ of reported cases, and more than $60 \%$ of seizures are complex partial (11). While several complications can develop, such as post-burn sepsis, compartment syndrome, electrolyte imbalance and pulmonary edema, seizures are rare. Episodes are in many cases precipitated by the head region coming into contact with hot water. This is followed, in decreasing order of 
frequency, by hot water coming into contact with the body, cold water coming into contact with the head and washing the face with hot water. Seizures are frequently complex and partial in hot water epilepsy (7). Hot water epilepsy is particularly observed in southern parts of India. The prevalence is 60/100,000. Most cases of epilepsy involving hot water have been reported in healthy children (1). Diagnosis of hot water epilepsy is generally made clinical at time of initial application. EEG is generally normal in the interictal period in these patients, while focal epileptic activities and paroxysmal discharges may be observed in the rictal period (5). As in our case, CT and MRG images from hot water epilepsy patients are almost always normal $(9,13)$. Intracranial malformation is rare in these patients (12). Antiepileptic drug therapy is not usually recommended after hot water epilepsy. The patient should be advised to bathe in warm water, and episodes can be prevented in this way (14). But if seizures recur despite bathing at normal temperatures, the patient should be started on antiepileptic therapy. Carbamazepine, lamotrigine and diphenylhydantoin are useful.

\section{CONCLUSION}

All forms of complication that may arise in patients presenting to the emergency department with burns should be borne in mind. Hot water epilepsy may be one of these rare complications. In addition to other causes, the emergency physician should also bear in mind hot water epilepsy, a form of reflex epilepsy. Hot water epilepsy may arise as the result of accident, and also in association with traditional bathing customs involving high-temperature water being applied to the head region and then to other regions of the body. Individuals undergoing seizures in this way should be advised to change their bathing habits if necessary and, in particular, to avoid their head regions coming into contact with water hotter than $45^{\circ} \mathrm{C}$. In addition, it must not be forgotten that treatment principles in hot water epilepsy do not differ from those in other seizures.

\section{REFERENCES}

1. Grosso S, Farnetani MA, Francione S, et al. Hot water epilepsy and focal malformation of the parietal cortex development. Brain Dev. 2004; 26(7): 490-3.

2. Incecik F, Hergüner MO, Elkay M, Altunbasak S. Hot water epilepsy-a report of three cases. Indian Pediatr. 2004; 41(7): 731-3.

3. Satishchandra P, Shivaramakrishna A, Kaliaperumal VG, Schoenberg BS. Hot water epilepsy: A variant of reflex epilepsy in Southern India. Epilepsia. 1988; 29(1): 52-6.

4. Satishchandra P. Geographically specific epilepsy syndromes in India. Hot water Epilepsy. Epilepsia. 2003; 44(1): 29-32.

5. Bebek N, Gürses C, Gokyigit A, Baykan B, Ozkara C, Dervent A. Hot water epilepsy: clinical and electrophysiologic findings based on 21 cases. Epilepsia. 2001; 42(9): 1180-4.

6. Yalcin D, Toydemir EH, Forta H. Hot water epilepsy: Clinical and electroencephalographic features of 25 cases. Epilepsy Behav. 2006; 9(1): 89-94.

7. Roos RA, van Dijk JG. Reflex-epilepsy induced by immersion in hot water. Case report and review of the literature. Eur Neurol .1988; 28(1): 6-10.

8. Gururaj G, Satischandra P. Correlates of hot water epilepsy in rural South India: a descriptive study. Neuroepidemiology. 1992; 11(4-6): 173-9.

9. Fukuda M, Morimoto T, Nagao H, Kida K. Clinical study of epilepsy with severe febrile seizures and seizures induced by hot water bath: Brain Dev. 1997; 19(3): 212-6.

10. Milanlığlu A, Tombul T, Sayın R. Hot water epilepsy in a pregnant woman: A case report. Case Report Med. 2010; 2010: 134578.

11. Savitha MR, Krishnamurthy B, Ashok DA, Ramachandra NB. Self abortion of attacks in 
patients with Hot Water Epilepsy. Indian Pediatr. 2007; 44(4): 295-8.

12. Tajima Y, Minami N, Sudo K, Moriwaka F, Tashiro K. Hot water epilepsy with pineal cyst and cavum septi pellucidi. Jpn J Psychiatry Neurol. 1993; 47(1): 111-4.

13. Erdem E, Topçu M, Renda Y, Ciğer A, Varli K, Zileli T. Hot water epilepsy. Clin Electroencephalogr 1992; 23(3): 152-8.

14. Kılbaş S, Koyuncuoğlu HR, Ayata A. Sıcak su epilepsisi: Bir vaka sunumu. Süleyman Demirel Üniversitesi Tıp Fakültesi Dergisi. 2007; 14(4): 302. 